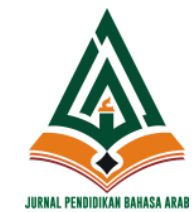

\author{
Alibbaa': Jurnal Pendidikan Bahasa Arab \\ Vol. 3 No. 1, January 2022 \\ P-ISSN: 2721-1606 | E-ISSN: 2716-4985 \\ doi: https://doi.org/10.19105/ajpba.v3i1.5108
}

\title{
Kohesi Leksikal Dalam Surah Al-Kahfi: Kajian Analisis Wacana
}

\author{
Nita Zakiah \\ Islamic Institute of NU Lampung, Indonesia \\ Corresponding E-mail: nitazakiah@,stainuku.ac.id
}

\begin{abstract}
Research on lexical cohesion in surah Al Kahfi aims to be known lexical relationship between parts of the text to get cohesive structural compatibility, in terms of words in the Qur'anic verse, or between verses with other verses. The study of lexical cohesion in surah Al-Kahfi used a descriptive qualitative approach. The data collection technique used was library research to obtain data. The method used in the data analysis stage was distributional method. Lexical cohesion in Surah Al Kahfi was proven by reiteration and collocation. Reiteration is repeating the words on the next sentence to give emphasis that the word is the object. The results of this research is that Reiteration in surab $A l K a b f i$ in the verses 32-33 and verse 51, a synonym in the verses 30-31 and verse 54, hyponym in the verses 34-35, verses 50 and 54, metonym in the verses $9-10$, and the antonym in the verses 18,63 , and 17 . Collocation is based on the relationship between the words in common the fact that frequently occurs around it, or link meaning between a single word in other words in the same context, such as in verses 17 and 29.
\end{abstract}

Keywords: Lexical Cohesion, Reiteration, Collocation. 


\section{Pendahuluan}

Al-Qur'an merupakan teks wacana paling kompleks. Karena di dalam al-Qur'an mengandung berbagai macam aspek dalam kehidupan manusia. Tata bahasa Al-Qur'an juga memiliki keindahan dan keterpautan antar-kata dan antar-ayat yang menjadikan teksnya kohesif dan koheren, serta saling berkesinambungan, hingga membentuk suatu kesatuan yang padu dan utuh. ${ }^{1}$

Sebagai satuan bahasa yang lengkap, di dalam wacana Al Qur'an terdapat konsep, gagasan, pikiran atau ide-ide yang bisa dipahami oleh pembaca. ${ }^{2}$ Karena itu, Al Qur'an menjadi objek penelitian yang di dalamnya terdapat magnet tersendiri, baik dari sisi substansi, maupun dari sisi gaya bahasa.

Gaya bahasa Al Qur'an terkait dengan variasi yang digunakan untuk mengungkapkan pesan dan maksud. Salah satu aspeknya adalah pada penggunaan kosakata atau aspek leksikal. Aspek leksikal yang terdapat di dalam al Qur'an diwujudkan melalui pemilihan kosakata (cohesive effect by the selection of vocabullary). ${ }^{3}$ Pemilihan kosakata ini berperan penting terhadap keterpautan antar-kata dan antar-kalimat, hingga membentuk suatu wacana yang lengkap.

Penelitian mengenai kohesi leksikal bertujuan agar dapat diketahui hubungan leksikal antara bagian-bagian teks untuk mendapatkan keserasian struktur secara kohesif, ${ }^{4}$ dari sisi antar kata di dalam ayat Al Qur'an, ataupun antar ayat dengan ayat yang lain. Khususnya, kajian mengenai kohesi leksikal yang terdapat dalam salah satu surat di dalam Al Qur'an yaitu Surat Al Kahfi -Selanjutnya disebut teks SA-.

Surat Al-Kahfi dianggap bisa mewakili ayat-ayat makiyah yang terdapat di dalam Al-Qur'an. Selain itu, pemilihan surat AlKahfi berdasarkan beberapa alasan: 1) Al-Kahfi memiliki

${ }^{1}$ Tarigan, H. G., Pengajaran Wacana, (Bandung: Angkasa, 1993), 27.

2 Alex Sobur, Analisis Teks Media, (Bandung: Remaja Rosdakarya, 2009), 10.

${ }^{3}$ Halliday, M.A.K., dan Ruqaiya Hasan. Cohesion in English. (London: Longman Group Ltd., 1976), 13.

${ }^{4}$ Mulyana, "Koherensi Wacana Sesorah Perkawinan Dalam Bahasa Jawa", (Yogyakarta: Tesis Program Pascasarjana Universitas Gadjah Mada, 2001), 9. 
keistimewaan pada penempatannya, yaitu terletak di pertengahan AlQur'an di akhir juz XV dan awal juz XVI; 2) Dari sisi stilistik, dari awal surat hingga akhir memiliki kesesuaian bunyi, berupa tanwin (nunation) yang dibaca akusatif karena berada di akhir kalimat; 3) dari sisi kandungan makna, di dalam surat ini mengandung beberapa kisah menarik dan amat populer, seperti kisah Ashabul Kahfi (penghuni gua), kisah Nabi Khidir dan Nabi Musa, kisah Dzulkarnain, dan beberapa kisah lainnya; 4) disebabkan di dalam teks SA banyak terdapat kisah-kisah, maka ditemukan pula dialog yang ditulis dengan kalimat langsung di dalam kisah yang diceritakan, di antaranya dialog antara sesama pemuda penghuni gua (Ashabul Kahfi), dialog antara pemuda mukmin dan kafir, dialog antara nabi Musa dengan pembantunya, serta nabi Musa dengan hamba Allah, dan lain-lain; 5) dan yang paling menarik adalah terdapat banyaknya pengulangan (reiterasi) seperti repetisi, pengulangan dengan kata bersinonim, pengulangan dengan kata yang berhiponim, dan yang paling banyak ditemukan adalah pengulangan dengan kata yang makna yang berlawanan (antonim).

Kajian mengenai Kohesi leksikal yang membahas wacana Bahasa Indonesia sudah banyak ditemukan penelitiannya. Seperti jurnal yang berjudul "Analisis Kohesi Gramatikal dan Leksikal pada Teks Eksposisi Siswa Kelas 10 Sekolah Menengah Atas" oleh Yustina Dwinuryati, Andayani, Retno Winarni. Penelitian tersebut membahas kohesi gramatikal dan leksikal pada teks eksposisi, khususnya pada siswa kelas 10. Kohesi gramatikal pada teks eksposisi diwujudkan dengan pengacuan (referensi), penyulihan (subtitusi), pelesapan (elipsis), dan perangkaian (konjungsi). Adapun kohesi leksikal diwujudkan dengan pengulangan (repetisi), padan kata (sinonimi), lawan kata (antonimi), hubungan atas bawah (hiponimi), sanding kata (kolokasi), dan kesepadanan (ekuivalensi). ${ }^{5}$ Penelitian lainnya, berjudul "Kohesi Leksikal Dan Kohesi Gramatikal dalam Novel Hujan Karya Tere Liye" oleh Hanifa Dwinda Khairunisa. Kajian dalam tulisan ini tidak hanya membahas kohesi leksikal, juga membahas kohesi gramatikal. Kohesi gramatikal diwujudkan dengan referensi, konjungsi, substitusi serta elipsis. Dan kohesi leksikal

5 Yustina Dwinuryati, Andayani, dan Retno Winarni, “Analisis Kohesi Gramatikal dan Leksikal pada Teks Eksposisi Siswa Kelas 10 Sekolah Menengah Atas." Scholaria, Jurnal Pendidikan dan Kebudayaan, Vol. 8 No. 1, 2018: 61-69. https://ejournal.uksw.edu/scholaria/article/view/1253 
diwujudkan dengan repetisi, sinonimi, antonimi, hiponimi, ekuivalensi dan kolokasi. ${ }^{6}$ Berbeda dengan dua jurnal sebelumnya yang membahas mengenai kohesi leksikal beserta kohesi gramatikalnya, penelitian Puput Puji Lestari, dkk. khusus mengkaji kohesi leksikal, yaitu "Kohesi Leksikal dalam Rubrik Politik Surat Kabar Kompas.", Hasil penelitian dalam tulisan ini, terdapat enam jenis kohesi leksikal, repetisi, sinonimi, antonimi, hiponimi, kolokasi, dan ekuivalensi dalam surat kabar Kompas dan kohesi leksikal. Penelitian ini menyatakan, sebagai bahan ajar bahasa Indonesia di SMK, materi kohesi menunjang kelengkapan materi klasifikasi kata berdasarkan bentuk kata, makna kata berdasarkan kelas kata, dan penggunaan kamus dalam mencari bentuk, kategori, dan makna kata.

Penelitian lain mengenai kohesi juga ditulis oleh Giati Anisah, yang berjudul "Kohesi Gramatikal dan Leksikal: Kajian pada Makalah Mahasiswa PAI." Tulisan ini tidak hanya mengkaji tentang kohesi leksikal, tetapi juga kohesi gramatikal pada makalah mahasiswa. Dalam makalah mahasiswa PAI tidaklah berbeda dengan kohesi gramatikal dan leksikal dalam ragam teks lain. Relasi semantis dalam hubungan kohesi, direalisasikan dalam sistem leksikogramatikal. Kohesi gramatikal berupa referensi, substitusi, elipsis, maupun konjungsi, dan kohesi leksikal yang berupa reiterasi dan kolokasi. ${ }^{8}$ Tidak jauh berbeda pada penelitian sebelumnya, Wardah Hanafiah mengkaji "Analisis Kohesi Dan Koherensi Pada Wacana Buletin Jumat." Kohesi gramatikal dalam buletin As-Salam diwujudkan dengan referensi, elipsis dan kongjungsi. Serta kohesi leksikal dalam buletin As-salam diwujudkan dalam bentuk repetisi, sinonim, hiponim, antonim, metonim dan kolokasi. ${ }^{9}$

6 Hanifa Dwinda Khairunisa, "Kohesi Leksikal Dan Kohesi Gramatikal Dalam Novel Hujan Karya Tere Liye.” Jurnal dari eprints Undip. 2019. http://eprints.undip.ac.id/77150/1/JURNAL_KOHESI_LEKSIKAL_DAN_KOHESI_ GRAMATIKAL_DALAM_NOVEL_HUJAN_KARYA_TERE_LIYE.pdf

${ }^{7}$ Puput Puji Lestari, Wiwik Darmini, dan Benedictus Sudiyana, "Kohesi Leksikal dalam Rubrik Politik Surat Kabar Kompas." KLITIKA: Jurnal Ilmiah Pendidikan Bahasa dan Sastra Indonesia, Vol. 2 No. 1, 2020: 76-87. http://journal.univetbantara.ac.id/index.php/klitika/article/view/761

${ }^{8}$ Giati Anisah, "Kohesi Gramatikal dan Leksikal: Kajian pada Makalah Mahasiswa PAI.” Indonesian Journal of Islamic Teaching, Vol. 2 No. 2, 2019:13-27. http://jurnalpasca.iain-jember.ac.id/ejournal/index.php/IJIT/article/view/610/100

${ }^{9}$ Wardah Hanafiah, "Analisis Kohesi dan Koherensi pada Wacana Buletin Jumat.” Epigram, Vol.11 No. 2, 2014:135-152.

https://jurnal.pnj.ac.id/index.php/epigram/article/view/676 
Penelitian kohesi leksikal terkini yaitu oleh Egi Ayis Ayurangga, Hetty Pelealu, dan Chistian Ranuntu, dengan judul: "Analisis Kohesi Leksikal pada Podcast "If You Keep Your Mouth Shut, You'll Be Surprised What You Can Learn" Oleh S.Town."10 Hasil analisis terhadap wacana pada podcast S.Town menunjukkan bahwa, pada podcast ini terdapat item-item kohesi leksikal, yaitu, reiterasi (repetisi, sinonimi, antonimi, hiponimi, dan metonimi), serta kolokasi. Pada dasarnya, penelitian ini tidak begitu berbeda dengan penelitian kohesi leksikal lainnya. Hanya saja, objek penelitiannya adalah podcast, bukanlah teks tertulis seperti pada umumnya.

Penelitian kohesi leksikal pada Al Qur'an belum banyak ditemui. Pada penelitian Hanifullah Syukri "Menghidupkan Alquran dari Perspektif Linguistik" tidak mengkaji kohesi leksikal secara khusus, hanya secara global. Namun, penelitian ini membahas kajian aspek linguistik di dalam Al Qur'an. Menurut Hanifullah, dengan memahami Al-Qur'an dari perspektif Linguistik, diperoleh integritas wacana Alquran yang lebih komprehensif. Lantas, analisis wacana merupakan metode yang dapat digunakan untuk memahami perspektif Linguistik Al Quran. ${ }^{11}$ Penelitian lain mengenai analisis wacana di dalam Al Qur'an juga ditulis oleh Toto Edidarmo, "Wacana Naratif Kehidupan Nabi Isa di dalam Al Qur'an." Penelitian ini mendeskripsikan mengenai wacana naratif kehidupan Nabi Isa secara sistematis di dalam Al Qur'an. Baik dari kelahirannya, kerasulannya, hingga nabi Isa Wafat. Jadi dalam penelitian ini tidak membahas kohesi namun khusus membahas analisis wacana naratif. ${ }^{12}$

Penelitian lain mengenai kohesi leksikal pada Al Qur'an, yaitu dengan judul "Kohesi Leksikal Antonimi Dalam Teks Terjemahan Al Quran (Surah Makiyyah)" oleh Retno Widaningsih. Kajian ini

${ }^{10}$ Egi Ayis Ayurangga, Hetty Pelealu, dan Chistian Ranuntu, “Analisis Kohesi Leksikal pada Podcast "If You Keep Your Mouth Shut, You'll Be Surprised What You Can Learn" Oleh S.Town.”Jurnal FIB Universitas Sam Ratulangi, Vol. 22, 2021: 1-14. https://ejournal.unsrat.ac.id/index.php/jefs/article/view/35480

${ }^{11}$ Hanifullah Syukri, "Menghidupkan Al Quran dari Perspektif Linguistik." Jurnal Sastra Indonesia. JSI, Vol. 8. No. 3. 2019: 188-196. https://journal.unnes.ac.id/sju/index.php/jsi/article/view/36021

${ }^{12}$ Toto Edidarmo, "Wacana Naratif Kehidupan Nabi Isa dalam Al Qur'an." Arabiyat: Jurnal Pendidikan Bahasa Arab dan Kebahasaaraban, Vol. 1 No. 1, 2014: 95-114. http://journal.uinjkt.ac.id/index.php/arabiyat/article/view/1133 
membahas variasi bentuk dan jenis kohesi leksikal antonimi dalam teks terjemahan Al Quran (surah Makiyyah), serta memaparkan makna teks terjemahan Al Quran (surah Makiyyah) yang mengandung antonimi. Jadi yang diteliti adalah teks terjemahannya, bukan teks Al Qur'annya. ${ }^{13}$ Penelitian lainnya berjudul: "Surat Al-Baqarah: Repetisi Sebagai Piranti Kohesi dalam Al-Qur'an" oleh Samsul Ma'arif. Sebagaimana penelitian Retno yang mengkaji satu aspek pada kohesi leksikal, penelitian ini juga fokus hanya pada satu aspek repetisi di dalam surat Al- Baqarah. Perbedaannya, penelitian ini mengkaji teks Al Qur'an, bukan teks terjemahan. ${ }^{14}$ penelitian lain mengenai kohesi leksikal juga dilakukan oleh Ery Sholichah, yang berjudul "Analisis Kohesi Leksikal Sinonimi Pada Teks Terjemahan Alquran Surah AnNahl." 15 Penelitian ini pun pembahasannya fokus pada satu aspek sinonimi saja. Dan yang dikaji bukan teks Al Qur'annya, namun pada teks terjemahannya. Sama seperti penelitian yang dilakukan oleh Retno.

Penelitian mengenai kohesi leksikal juga ditulis oleh Nurul Azizah Putri Palupi, Ilfia Rahmi Rasyid, dan Nur Hizbullah dengan judul: "Repetisi Leksikal pada Al-Quran Surat Al-Kafirun." Berdasarkan penelitian, repetisi dari surat Al-Kafirun menunjukkan bahwa repetisi pada surat Al-Kafirun terdapat repetisi sempurna atau secara keseluruhan (repetited form) berupa kata, frasa, klausa dan kalimat. Repetisi sempurna atau secara keseluruhan adalah pengulangan dengan penambahan kata lain. Dan dalam repetisi ini, kita dapat melihat dan membedakan referensi dari setiap pengulangan yang ada. Jadi, fokus penelitian ini pada satu aspek kohesi leksikal, yaitu repetisi atau pengulangan. ${ }^{16}$

\footnotetext{
${ }^{13}$ Retno Widaningsih, "Kohesi Leksikal Antonimi dalam Teks Terjemahan Alquran (Surah Makiyyah).” (Surakarta: Skripsi UMS, 2015). http://eprints.ums.ac.id/28562/

${ }^{14}$ Samsul Ma'arif, "Surat Al-Baqarah: Repetisi Sebagai Piranti Kohesi dalam Al-Qur'an,” Jurnal Al-Itqan, Vol. 2 No. 1, 2016: 1-18. https://jurnal.staialanwar.ac.id/index.php/itqon/article/view/15

${ }^{15}$ Ery Sholichah, "Analisis Kohesi Leksikal Sinonimi Pada Teks Terjemahan Alquran Surah An-Nahl,” Skripsi Fakultas Keguruan Dan Ilmu Pendidikan Universitas Muhammadiyah Surakarta 2014. http://eprints.ums.ac.id/28562/17/NASKAH_PUBLIKASI.pdf

${ }^{16}$ Nurul Azizah Putri Palupi, Ilfia Rahmi Rasyid, dan Nur Hizbullah. “Repetisi Leksikal pada Al-Quran Surat Al-Kafirun” Prosiding Seminar Nasional
} 
Penelitian lainnya yaitu, penelitian yang dilakukan oleh $\mathrm{M}$. Kamal yang berjudul "Kohesi dan Koherensi Dalam Teks Bahasa Arab" penelitian ini mengkaji tentang kohesi dan koherensi pada teks berbahasa Arab. Bukan pada teks Al Qur'an. ${ }^{17}$ Penelitian terdahulu lainnya adalah "Kohesi dan Koherensi Kisah Nabi Yusuf di dalam Al Qur'an" oleh Afif Kholisun Nashoih. Penelitian tersebut mengkaji kohesi dan koherensi di dalam kisah nabi Yusuf, menguraikan pirantipiranti kohesi dan koherensi yang membentuk keterpaduan secara utuh pada wacana kisah nabi Yusuf. Di dalam penelitian, kohesi leksikal tidak dibahas secara khusus. Karena fokus kajiannya ada pada keutuhan makna yang dibentuk oleh kohesi (bentuk) dan koherensi (makna) dalam kisah Nabi Yusuf. ${ }^{18}$

Jadi, penelitian di dalam jurnal ini memiliki perbedaan yang jelas, baik dari aspek objek formal, maupun material dengan penelitian terdahulu yang sudah ada. Mengingat bahwa Al Qur'an memiliki keistimewaan pada gaya bahasa yang digunakan, bahkan di setiap surat di dalam al Qur'an memiliki gaya bahasa yang tidak sama. Maka penelitian mengenai kohesi leksikal di dalam Al Qur'an tentu saja masih relevan dan terbuka untuk dikaji lebih dalam.

\section{Metode Penelitian}

Metode penelitian merupakan alat, prosedur, dan teknik yang dipilih dalam melaksanakan penelitian. ${ }^{19}$ Istilah metode di dalam penelitian linguistik dapat ditafsirkan sebagai strategi kerja berdasarkan ancangan tertentu. ${ }^{20}$ Ancangan tersebut merupakan kerangka berpikir dalam penentuan metode dan teknik penelitian, khususnya teknik

Linguistik dan Sastra (SEMANTIKS), 2019.

https://jurnal.uns.ac.id/prosidingsemantiks/article/view/39413

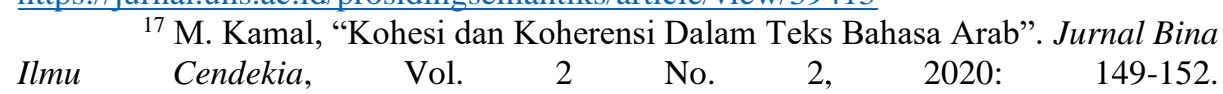
https://jurnal.icjambi.id/index.php/jbic/article/view/115

18 Afif Kholisun Nashoih, "Kohesi dan Koherensi Kisah Nabi Yusuf dalam Al Qur'an.” (Yogyakarta: Tesis UIN Sunan Kalijaga. 2015). http://digilib.uinsuka.ac.id/id/eprint/17602/

${ }^{19}$ Fatimah Djajasudarma, Metode Linguistik: Ancangan Metode Penelitian dan Kajian, (Bandung: PT Refika Aditama. 2006), 4.

${ }^{20}$ Edi Subroto, Pengantar Metode Penelitian Linguistik Struktural, (Surakarta: Lembaga Pengembangan Pendidikan (LPP) UNS, dan UPT Penerbitan dan Pencetakan UNS (UNS Press), 2007), 36. 
pengumpulan dan analisis data. Kajian kohesi leksikal dalam surat AlKahfi ini menggunakan pendekatan kualitatif deskriptif. Teknik pengumpulan data yang digunakan adalah teknik pustaka dengan mempergunakan sumber-sumber tertulis untuk memperoleh data. Dan data kebahasaan yang diambil dari sumber pustaka tertentu, dibatasi pada kepentingannya terhadap maksud dan tujuan penelitian. Adapun Metode yang digunakan dalam tahap analisis data adalah metode distribusional (distributional method). ${ }^{21}$

Teknik metode distribusional yang digunakan adalah teknik bagi unsur langsung sebagai teknik dasarnya, dengan teknik lanjutan berupa teknik baca markah. Teknik analisis data ini digunakan dengan cara membagi suatu konstruksi menjadi beberapa bagian atau unsur, dan bagian-bagian atau unsur-unsur itu dipandang sebagai bagian atau unsur yang langsung membentuk konstruksi yang dimaksud dengan fungsi menentukan bagian-bagian fungsional. ${ }^{22}$ Teknik ini bertujuan untuk memperjelas fungsi masing-masing unsur dalam kalimat. Teknik baca markah digunakan untuk memahami hubungan antarkata, klausa ataupun kalimat dengan cara membaca pemarkah atau tanda dalam suatu konstruksi kebahasaan.

\section{Hasil dan Pembahasan}

Kohesi leksikal adalah hubungan leksikal antara bagian-bagian teks untuk mendapatkan keserasian struktur secara kohesif. Renkema mengklasifikasikan kohesi leksikal menjadi dua: reiterasi dan kolokasi. Prinsip kedua jenis tersebut adalah membentuk kohesi melalui kesinambungan makna leksikal. ${ }^{23}$

Kesinambungan makna leksikal yang direalisasikan dengan pengulangan (reiterasi) dan sanding kata (kolokasi) menjadi penunjang kekohesifan dalam teks SA. Pengulangan (reiterasi) banyak ditemukan di dalam teks SA dengan lima tipe pengulangan, pengulangan dengan kata yang sama atau hampir sama (repetisi), pengulangan dengan kata yang maknanya bersinonim, pengulangan dengan kata yang maknanya berhiponim, pengulangan dengan kata yang maknanya berantonim, dan

21 Sudaryanto, Metode dan Aneka Teknik Analisis Bahasa. (Yogyakarta: Duta Wacana University Press. 1993), 15.

${ }^{22}$ Ibid., 31 .

23 Jan Renkema, Introduction to Discourse Studies. (Amsterdam: John Benjamins Publishing Company), 105. 
pengulangan dengan metonimi. Selain pengulangan, kekohesifan teks juga direalisasikan dengan kolokasi atau sanding kata. Adapun kohesi leksikal yang ada pada teks SA adalah sebagai berikut.

\section{Reiterasi}

Berdasarkan pertalian kohesi secara leksikal, reiterasi atau pengulangan dapat dicapai melalui penggunaan kata yang terhubung dengan sebelumnya secara sistematis. Reiterasi diklasifikasikan menjadi lima tipe: (1) repetisi, (2) sinonimi, (3) hiponimi/hiperonimi, (4) metonimi, dan (5) antonimi. ${ }^{24}$ Pada teks SA kelima jenis reiterasi ini berfungsi sebagai pengutuh teks. Sebagaimana dijelaskan pada masingmasing sub-bab berikut dengan disertai contoh dari masing-masing tipe pengulangan (reiterasi).

\section{a. Repetisi}

Repetisi disebut dengan tikräriyah ${ }^{25}$ merupakan pengulangan kata-kata yang sama atau hampir sama yang berfungsi untuk mempertahankan kohesi antarkalimat. Hubungan itu dibentuk dengan mengulang sebagian unsur kalimat, karena pengulangan yang berlebihan dapat membosankan. Pengulangan itu berarti mempertahankan ide atau topik yang sedang dibicarakan. Jadi, dengan mengulang, berarti terkait antara topik kalimat yang satu dengan kalimat sebelumnya yang diulang.

Di dalam teks SA, repetisi atau pengulangan kata terjadi antar kalimat. Sebagaimana data berikut.

1) Waựib lahum maśalā rajulaini ja'alnā li ạ̣adihimā jannataini min a'nābin wa ḥafafnāhumā bi nakhlin wa ja'alnā bainahumā zar'ā. Kiltā al-jannataini àtat ukulahā wa lam tazlim minhu syaia'n wa fajjarnā khilālahumā naharā (SA: 32-33).

'Dan berikanlah kepada mereka sebuah perumpamaan dua orang laki-laki, Kami jadikan bagi seorang di antara keduanya (yang kafir) dua buah kebun anggur dan Kami kelilingi kedua kebun itu dengan pohon-pohon korma dan di antara kedua kebun itu Kami buatkan ladang. Kedua buah kebun itu menghasilkan buahnya, dan kebun itu tiada kurang buahnya

${ }^{24}$ Jan Renkema. Introduction to Discourse Studies, 105.

25 Muhammad Ali Al-Khulli, Mu'jam 'Ilm Al-Lughati An-Nazariyyi/A Dictionary of Theoretical Linguistics English-Arabic. (Beirut: Lebrairie du Liban. 1982), 345. 
sedikitpun, dan Kami alirkan sungai di celah-celah kedua kebun itu.'

2) Mā asyhadtuhum khalqa as-samāwāti wa al-ardi wa là khalqa anfusihim wa mā kuntu muttakhiża al-mudillina 'ạ̣duda (SA: 51).

'Aku tidak mempersaksikan mereka penciptaan langit dan bumi dan tidak (pula) penciptaan diri mereka; dan tidaklah Aku mengambil para penyesat itu sebagai penolong.'

Pada data (1) terdiri dari kalimat-kalimat, yaitu:

a. Wadrib lahum maśalā rajulaini

b. Ja'alnā li ahadihimā jannataini min a'nābin

c. Wa hafafnāhumā bi nakhlin wa ja'alnā bainahumā zar'a

d. Kiltà al-jannataini ātat ukulahā

e. Wa lam tazlim minhu syai'an

f. Wa fajjarnà khilālahumā nahara

Kohesi leksikal dengan tipe repetisi antarkalimat di atas dicapai melalui pengulangan sebagian, yaitu pengulangan bentuk /jannataini min a'nābin/ 'dua kebun anggur' pada kalimat (1.b), diulangi dengan pengulangan sebagian bentuknya /al-jannatainil 'dua buah kebun' pada kalimat (1.d).

Pada data (2) terdiri dari tiga kalimat.

a. Mā asyhadtuhum khalqa as-samāwāti wa al-arḍi

b. Wa là khalqa anfusihim

c. Wa mā kuntu muttakhiża al-mudillinina 'aḍdā

Repetisi atau pengulangan leksikal antarkalimat di atas diwujudkan dengan pengulangan verbal noun (mașdar) / khalqal 'penciptaan' pada kalimat (2.b) yang telah disebutkan pada kalimat (2.a). Verbal noun / khalqal diulangi kembali dengan bentuk yang serupa.

Repetisi pada nomina /jannataini/ dan verbal noun / khalqa/ diulangi untuk menekankan pentingnya kata tersebut dalam kalimat. Kata /jannatainil memiliki makna yang serupa dengan kata yang sebelumnya /jannataini min a'nābin/ 'dua kebun anggur', hanya saja karena pengulangan bersifat sebagian /jannataini/ 'dua kebun' maka makna yang diulangi juga hanya sebagian, tetapi yang dimaksud adalah kebun anggur. Adapun kata verbal noun / khalqal mempunyai arti yang sama dengan kata yang sebelumnya. Pertalian kohesi yang 
dicapai melalui pengulangan dengan kata yang sama atau serupa pada teks SA merupakan salah satu penanda hubungan leksikal yang terjalin antarkalimat di dalam teks.

\section{b. Sinonimi}

Sinonimi adalah bentuk bahasa yang maknanya mirip atau sama dengan bentuk lain. ${ }^{26}$ Sinonimi dalam kepaduan teks diwujudkan dengan adanya hubungan di antara unsur-unsur bahasa yang mirip atau sama maknanya, dan hubungan ini terdapat di dalam kalimat-kalimat pembentuk keutuhan teks. Yang dimaksud sinonim di sini adalah satuan bahasa, dan satuan bahasa ini merupakan bagian dari reiterasi atau pengulangan, hanya saja pengulangan di dalam sinonim merupakan pengulangan makna karena memiliki bentuk yang berbeda tidak seperti pada repetisi yang merupakan pengulangan bentuk dan makna. Di dalam linguistik Arab, istilah sinonimi sepadan dengan tarāduf.

Reiterasi leksikal yang diwujudkan dengan sinonimi pada teks SA dapat dilihat pada data berikut.

3) Inna al-lazīna āmanū wa 'amilū aś-sālihāti innā lā nựi'u ajra man aḥsana 'amala. Ūlāi'ka lahum jannātu 'adnin tajrī min tạ̣tihimu al-anhāru yuḥallauna fīha min asāwira min żahabin wa yalbasiuna siyāban khudran min sundusin wa istabraqin muttaki'ina fīhà 'ala al-arā'iki ni'ma aś-sawābu wa hasunat murtafaqā (SA: 30-31).

'Sesungguhnya mereka yang beriman dan beramal saleh, tentulah Kami tidak akan menyia-nyiakan pahala orang-orang yang mengerjakan amalan(nya) dengan yang baik. Mereka itulah (orang-orang yang) bagi mereka surga 'Adn, mengalir sungai-sungai di bawahnya; dalam surga itu mereka dihiasi dengan gelang mas dan mereka memakai pakaian hijau dari sutera halus dan sutera tebal, sedang mereka duduk sambil bersandar di atas dipan-dipan yang indah. Itulah pahala yang sebaik-baiknya, dan tempat istirahat yang indah.'

4) Walaqad șarrafnā fì haża al-qur'āni lin-nāsi min kulli maśalin wa kāna al-insānu akśaru syai'in jadalāa (SA: 54)

${ }^{26}$ Harimurti Kridalaksana, Kamus Linguistik, (Jakarta: PT Gramedia Pustaka Utama), 222. 
'Dan sesungguhnya Kami telah mengulang-ulangi bagi manusia dalam Al-Quran ini bermacam-macam perumpamaan. Dan manusia adalah makhluk yang paling banyak membantah.'

Pada data (3) kohesi leksikal dicapai melalui reiterasi atau pengulangan aspek leksikal yang maknanya mirip atau sama dengan bentuk lain (bersinonim) antara kata /ajral 'pahala' pada kalimat /Inna

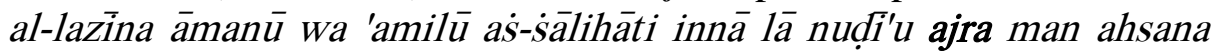

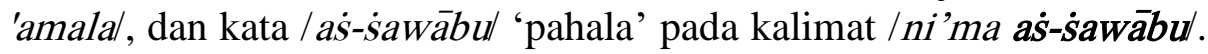
Pengulangan yang berupa sinonimi pada kata /ajra/ dan /aś-śawābul menandai hubungan leksikal antarkalimat yang terdapat di dalam teks. Dan kedua kata bersinonim ini merupakan bagian dari unsur pembentuk keutuhan teks.

Kohesi leksikal pada data (4) dicapai melalui pengulangan aspek leksikal yang maknanya mirip atau sama dengan bentuk lain (bersinonim) antara kata /an-nās/ 'manusia' pada kalimat / Walaqad șarrafnā fì hàża al-qur'āni li an-nāsi min kulli maśalin/ dan diulangi dengan kata /al-insānul 'manusia' yang merupakan sinonim dari kata /an-nās/ pada kalimat / wa kāna al-insānu akśaru syai'in jadalāl. Pengulangan leksikal dengan sinonimi pada kata /an-nās/ dan /alinsānul menandai hubungan leksikal antarkalimat. Kedua kata bersinonim ini menjadi aspek leksikal pembentuk keutuhan di dalam teks SA.

\section{c. Hiponimi}

Hiponimi merupakan bagian dari tipe reiterasi atau pengulangan di dalam kohesi leksikal. Hiponimi adalah pengulangan yang berdasarkan hubungan antara makna spesifik dan makna generik. ${ }^{27}$ Unsur bahasa yang bermakna spesifik disebut sebagai hiponim, dan unsur yang mermakna generik disebut sebagai superordinat.

Di dalam 'ilm ad-dalālah (semantik), hiponimi disebut dengan al-isytimāl. ${ }^{28}$ Hiponimi berkaitan dengan ițāa di dalam 'ilm al-

${ }^{27}$ Harimurti Kridalaksana. Kamus Linguistik, 83.

${ }^{28}$ Ahmad Mukhtar Amar. 'ilm ad-ḍalālah. (Cairo: Âlim Al-Kutub. 1998), 66. 
balāgah ma'āni. It nāab adalah bidang yang membahas pemanjangan bentuk kalimat dalam mengutarakan maksud tertentu. ${ }^{29}$

Di dalam teks SA, pengulangan kata berhiponim dicapai melalui penyebutan kata yang bermakna umum (superordinat) setelah menyebutkan kata yang bermakna khusus (spesifik) (żikru al-'ām ba'da al-khạs). Sebagaimana data berikut.

5) Wa kāna lahu śamarun faqāla liṣāhịibihi wa huwā yuḥ̄āwiruhu anā akśara minka mālan wa a'azzu nafarā wa dakhala jannatahu wa huwa zālimun linafsihi qāla mā azunnu an tabìda hàżihi abada (SA: 34-35).

'Dan dia mempunyai kekayaan besar, maka ia berkata kepada kawannya (yang mukmin) ketika bercakap-cakap dengan dia: "Hartaku lebih banyak dari pada hartamu dan pengikutpengikutku lebih kuat." dan dia memasuki kebunnya sedang dia zalim terhadap dirinya sendiri; ia berkata: "Aku kira kebun ini tidak akan binasa selama-lamanya."”

6) Wa iż qulnā li al-malā'ikati usjudū li Ādama fasajadū illā iblisa kāna minal jinni fafasaqa 'an amri rabbihi.. (SA: 50).

'Dan (ingatlah) ketika Kami berfirman kepada Para Malaikat: "Sujudlah kamu kepada Adam, Maka sujudlah mereka kecuali iblis. Dia adalah dari golongan jin, Maka ia mendurhakai perintah Tuhannya.'

Pada data (5), pengulangan kata berhiponim diwujudkan dengan żikru al-'ām ba'da al-khās, yaitu unsur kata yang bermakna spesifik (al-khăs) disebutkan terlebih dahulu, kemudian diulangi dengan unsur kata yang bermakna generik atau superordinat (al-'ām). Hiponimi diawali dengan menyebutkan kata yang bermakna spesifik / samarun/ 'buah' pada kalimat / Wa kāna lahu śamarun/ yang kemudian diulangi dengan kata yang bermakna superordinat /jannatun/ 'kebun' (kebun yang di maksud adalah kebun anggur /jannatun min a'nāb/) pada kalimat / wa dakhala jannatahū wa huwa zālimun li-nafsihil. Kata yang bermakna generik /śamarun/ merupakan bagian dari kata yang bermakna superordinat /jannatun/, dimana buah merupakan hasil dari kebun.

${ }^{29}$ Ahmad Hasyimi, Jauhar Al-Balāgah fí Al-Ma’āni wa Al-Bayān wa AlBadi’, (Beirut: Dār Al-Fikr. 1994), 196. 
Sebagaimana pada data (5), reiterasi dengan hiponimi pada data (6) juga merupakan bagian dari hiponimi dengan żikru al- 'ām ba'da alkhās. Diawali dengan menyebutkan kata yang bermakna spesifik/iblis/ 'iblis' pada kalimat /Wa iż qulnā lil malāikati usjudū li ÁAama fasajadū illā iblisal, kemudian diulangi dengan kata yang bermakna generik atau super-ordinat /jin/ 'jin'. Iblis (sebagaimana keterangan dalam ayat) merupakan bagian dari golongan jin.

Pengulangan yang berupa hiponimi pada kata /samarun/ dan /jannatun/, serta pengulangan pada kata /iblis/ dan /jin/, keduanya menandai hubungan leksikal antarkalimat di dalam teks SA.

Pengulangan kata berhiponim juga dicapai melalui penyebutan kata yang bermakna khusus (spesifik) setelah menyebutkan kata yang bermakna umum (superordinat), atau disebut dengan (żikru al-'ām ba'da al-khās). Sebagaimana data berikut.

7) Walaqad șarrafnā fì hàża al-qur'āni li an-nāsi min kulli maśalin wa kāna al-insānu aksaru syai'in jadalā (SA: 54).

'Dan sesungguhnya Kami telah mengulang-ulangi bagi manusia dalam Al-Quran ini bermacam-macam perumpamaan. Dan manusia adalah makhluk yang paling banyak membantah.'

Pada data (7), pengulangan kata berhiponim diwujudkan dengan żikru al-khas ba'da al-‘àm, yaitu menyebutkan kata yang bermakna generik atau super-ordinat setelah menyebutkan kata yang bermakna spesifik. Hiponimi diawali dengan menyebutkan kata yang bermakna generik /al-qur'ān/ 'Al-Qur'an', kemudian diulangi dengan menyebutkan kata yang bermakna spesifik / maśalin/ 'perumpamaan', di mana perumpamaan-perumpamaan yang dimaksud adalah perumpamaan yang terdapat di dalam Al-Qur'an. Dengan demikian, 'perumpamaan' merupakan kata yang bermakna khusus, sedangkan 'Al-Qur'an' adalah kata yang bermakna umum, maksudnya adalah perumpamaan merupakan bagian dari apa yang terkandung di dalam Al-Qur'an. Pengulangan yang berupa hiponimi pada kedua kata tersebut terjadi pada tataran intrakalimat karena berada di dalam kalimat yang sama / Walaqad șarrafnā fì hàża al-qur'āni lin-nāsi min kulli masalin/.

\section{d. Metonimi}

Metonimi adalah pengulangan dengan menggunakan nama untuk benda lain yang berasosiasi atau yang menjadi atributnya. Dalam 
bahasa Indonesia misalnya, "Si kacamata" yang ditujukan kepada orang yang menggunakan kacamata.

Di dalam teks SA fenomena metonimi tampak pada pemakaian nama /aṣhābul kahfil 'penghuni gua', nama ini ditujukan kepada para pemuda yang mencari tempat berlindung ke dalam gua, penamaan Iaṣhābu al-kahfi/ berasosiasi kepada benda yang berupa suatu tempat Ikahfil 'gua' tempat mereka tertidur. Dan frase tersebut digunakan untuk mencapai makna yang sesungguhnya, bukan makna leksikalnya. Karena makna leksikalnya menunjukkan bahwa mereka adalah penghuni gua, padahal gua hanyalah tempat mereka bersembunyi. Jadi yang makna yang dikehendaki adalah makna sesungguhnya, bukan makna leksikalnya. Sebagaimana pada data berikut.

8) Am hasibta anna așhāba al-kahfi wa ar-raqīmi kānū min àyātinā 'ajabā. İ́ awā al-fityatu ila al-kahfi faqā̄ū rabbanā $\bar{a}$ tinā min ladunka rahmatan wa hayyi' lanā min amrinā rasyadă (SA: 9-10).

'Apakah kamu mengira bahwa aṣhābu al-Kahf dan ar-raqīm adalah mereka yang merupakan tanda-tanda kekuasaan Kami yang mengherankan? Tatkala pemuda-pemuda itu mencari tempat berlindung ke dalam satu gua, lalu mereka berdoa: "Tuhan kami! Anugerahilah kami dari sisi-Mu rahmat dan siapkanlah bagi kami untuk urusan kami petunjuk."'

Reiterasi yang berupa metonimi pada data (8) diawali dengan penyebutan metoniminya terlebih dahulu yaitu frase nominal /aşhāba al-kahfil, dan diulangi dengan kata /al-fityatu/ 'pemuda-pemuda' yang tidak lain adalah para penghuni gua /așhāba al-kahfil.

\section{e. Antonimi}

Antonimi merupakan oposisi makna dalam pasangan leksikal yang dapat dijenjangkan. ${ }^{30}$ Antonimi di dalam kohesi leksikal merupakan bagian dari tipe reiterasi yang digunakan untuk mengulang kata atau frase yang maknanya saling berlawanan.

Antonimi di dalam 'ilm ad-dalālah (semantik) disebut dengan at-tad̆àd. Konsep antonimi di dalam 'ilm al-balāgah al-badi' sepadan dengan konsep at-tibāq, yaitu berkumpulnya dua bentuk kata yang maknanya saling berlawanan di dalam satu kalimat. Tiba $q$ dibedakan menjadi dua, țibāq $\bar{i} j a b$ dan tibāq salab. Disebut tibàq $\bar{i} j a b$ jika kedua

\footnotetext{
${ }^{30}$ Harimurti Kridalaksana. Kamus Linguistik, 17.
} 
kata yang berlawanan tidak berbeda positif atau negatifnya, sedangkan tibāq salab jika kedua kata yang berlawanan berbeda positif atau negatifnya. Seperti pada data berikut.

9) Wa tahsabuhum aiqāzā wa hum ruqūdun.. (SA: 18)

'Dan kamu mengira mereka itu bangun, padahal mereka tidur.'

10) Qàla ara'aita iż awainā ilā aș-ṣakhrati fa-innī nasìtu al-ḥùta wa mā ansānīhu illā asy-syaițānu an ażkurahu.. (SA: 63).

'Dia berkata, "Tahukah kamu tatkala kita mecari tempat berlindung di batu tadi, maka sesungguhnya aku lupa ikan itu dan tidak menjadikan aku melupakannya kecuali syaitan."

Pada data (9), reiterasi dengan antonimi diwujudkan dengan dua bentuk kata yang maknanya saling berlawanan di dalam satu kalimat yaitu kata /aiqāāal 'bangun' pada klausa / Wa tạ̣sabuhum aiqāāal yang diulangi dengan kata yang berantonim / ruqüdun/ 'tidur' pada klausa / wa hum ruqūdun/. Antonimi pada kedua kata ini disebut juga dengan tibāq $\bar{i} j a b$, karena kedua kata yang berlawanan tidak berbeda positif atau negatifnya.

Reiterasi dengan antonimi pada data (10) diwujudkan dengan dua bentuk kata yang maknanya saling berlawanan, yaitu kata /nasitu/ 'aku lupa' pada kalimat /ara'aita iż awainā ilā as-ṣakhrati fa-inn $\bar{i}$ nasitu al-ḥuta/ yang diulangi dengan kata yang diiringi dengan partikel negasi hingga maknanya berlawanan / $m \bar{a}$ ansānīhu/ 'tidak menjadikan aku lupa' pada kalimat / wa mā ansānīhu illā asy-syaitānu an ażkurahu/. Antonimi pada kedua kata ini disebut juga dengan tibāq salab karena kedua kata yang berlawanan berbeda positif atau negatifnya.

Konsep antonimi juga sepadan dengan muqābalah dalam 'ilm al-balāgah al-badi', hanya saja pada muqābalah kata yang maknanya berlawanan tidak hanya satu, namun menyatakan dua bentuk atau lebih dan menyatakan kebalikannya secara berurutan atau berselang. Sebagaimana pada data berikut.

11) Wa tarā asy-syamsa iża tala'at tazāwaru 'an kahfihin żāta alyamīni wa iżà garabat taqrị̣uhum żāta asy-syimāi wa hum fi fajwatin minhu, zàlika min àyātillahi, man yahdi Allah fa huwa al-muhtadi, wa man yudlil fa lan tajida lahu waliyyan mursyida (SA: 17).

'Dan kamu melihat matahari ketika terbit, condong dari gua mereka ke sebelah kanan dan bila matahari itu terbenam ia 
menjauhi mereka ke sebelah kiri sedang mereka berada dalam tempat yang luas di dalamnya. Itu adalah sebagian dari ayatayat Allah. Barangsiapa yang diberi petunjuk oleh Allah maka dialah yang mendapat petunjuk; dan barangsiapa yang disesatkan-Nya, maka kamu tidak akan mendapatkan baginya seorang pemimpin yang menjadi pembimbing.'

Pada data (11), kohesi leksikal dicapai melalui pengulangan beberapa kata yang maknanya saling berlawanan yang tersusun secara berurutan, seperti tampak di dalam kalimat / Wa tarā asy-syamsa iża tala'at tazāwaru 'an kahfihim żāta al-yaminil dan kalimat /wa iżā garabat taqrị̣uhum żăta asy-syimali/ terletak berurutan, verba /tala'at/ 'terbit' diulangi dengan verba yang maknanya berlawanan /garabat/ 'terbenam'; verba / tazầarul 'condong' diulangi dengan verba yang maknanya berlawanan /taqrị̣ul 'menjauhi'; frase nominal /żāta alyaminīil 'sebelah kiri' diulangi dengan frase nominal yang maknanya berlawanan /żàta asy-syimālil 'sebelah kanan'. Pada kalimat berikutnya /man yahdi Allah fa huwa al-muhtadil dan kalimat / wa man yuḍlil fa lan tajida lahu waliyyan mursyidàl, verba /yahdil 'diberi petunjuk' diulangi dengan verba pasif yang maknanya berlawanan /yuḍlill/ 'disesatkan.'

\section{f. Kolokasi}

Kolokasi atau sanding kata di dalam kohesi leksikal adalah hubungan antarkata berdasarkan kesamaan fakta yang sering terjadi di sekelilingnya, atau pertautan makna antara satu kata dengan kata lain di lingkungan yang sama. Di dalam teks SA, kohesi leksikal juga dicapai melalui pengulangan unsur leksikal berupa kolokasi atau sanding kata. Sebagaimana data berikut.

12) ..Man yahdi Allah fa huwa al-muhtadi wa man yuḍlil falan tajida lahu waliyyan mursyidā ( SA:17).

'Barangsiapa yang diberi petunjuk oleh Allah maka dialah yang mendapat petunjuk; dan barangsiapa yang disesatkanNya, maka kamu tidak akan mendapatkan baginya seorang pemimpin yang menjadi pembimbing.

13) .. Wa in yastagīisu yugāsiu bi māi'n kal-muhli yasywī al-wujūha bi'sa asy-syarābu wa sā'at murtafaqā (SA: 29).

'..Dan jika mereka meminta minum, niscaya mereka akan diberi minum dengan air seperti besi yang mendidih yang 
menghanguskan muka. Itulah minuman yang paling buruk dan tempat istirahat yang paling jelek.'

Pada data (12), kohesi leksikal dicapai melalui penyandingan kata /al-muhtadi / 'orang yang diberi petunjuk' dengan frase / waliyyan mursyidā' 'pemimpin yang diberi petunjuk'. Hubungan di antara kedua kata tersebut adalah kedua kata ini berada di lingkungan yang sama, yaitu sama-sama termasuk orang yang mendapat petunjuk dari Allah.

Kohesi leksikal Pada data (13) dicapai melalui penyandingan kata / asysyarābu/ 'minuman' dengan kata / māun/ 'air'. Hubungan di antara kedua kata tersebut amat jelas, karena minuman selalu mengarah pada benda yang berwujud air. Kedua kata tersebut merupakan bagian dari kolokasi karena berada di lingkungan yang sama.

\section{Kesimpulan}

Kohesi leksikal dalam teks SA diwujudkan dengan reiterasi (repetisi, sinonimi, hiponimi, metonimi, serta antonimi) dan kolokasi. Reiterasi yang berbentuk pengulangan kata-kata pada kalimat berikutnya untuk memberikan penekanan bahwa kata tersebut merupakan fokus pembicaraan dalam teks SA berupa: (1) Repetisi, seperti dalam ayat 32-33 dan ayat 51; (2) Sinonimi, dalam ayat 30-31 dan ayat 54; (3) Hiponimi, dalam ayat 34-35, ayat 50 dan ayat 54; (4) Metonimi ayat 9-10; dan (5) Antonimi, dalam ayat 18, 63, dan ayat 17.

Adapun kolokasi atau sanding kata yang diwujudkan dengan hubungan antarkata berdasarkan kesamaan fakta yang sering terjadi di sekelilingnya, atau pertautan makna antara satu kata dengan kata lain di lingkungan yang sama di dalam teks SA, contohnya seperti pada ayat 17 dan ayat 29. 


\section{Daftar Pustaka}

Afif Kholisun Nashoih, "Kohesi dan Koherensi Kisah Nabi Yusuf dalam Al Qur'an.” Yogyakarta: Tesis UIN Sunan Kalijaga. 2015.

Ahmad Hasyimi. Jauhar Al-Balagah fi Al-Ma'ani wa Al-Bayan wa AlBadi'. Beirut: Da>r Al-Fikr. 1994.

Ahmad Mukhtar Amar. 'ilm ad-dalalah. Cairo: Alim Al-Kutub. 1998.

Alex Sobur, Analisis Teks Media, Bandung: Remaja Rosdakarya, 2009.

Edi Subroto, Pengantar Metode Penelitian Linguistik Struktural. Surakarta: Lembaga Pengembangan Pendidikan (LPP) UNS, dan UPT Penerbitan dan Pencetakan UNS (UNS Press). 2007.

Egi Ayis Ayurangga, Hetty Pelealu, dan Chistian Ranuntu, "Analisis Kohesi Leksikal pada Podcast "If You Keep Your Mouth Shut, You'll Be Surprised What You Can Learn" Oleh S. Town." Jurnal FIB Universitas Sam Ratulangi. Vol. 22, 2021: 1-14. https://ejournal.unsrat.ac.id/index.php/jefs/article/view/35480

Ery Sholichah, "Analisis Kohesi Leksikal Sinonimi Pada Teks Terjemahan Alquran Surah An-Nahl," Skripsi Fakultas Keguruan Dan Ilmu Pendidikan Universitas Muhammadiyah Surakarta 2014.

Fatimah Djajasudarma, Metode Linguistik: Ancangan Metode Penelitian dan Kajian. Bandung: PT Refika Aditama. 2006.

Giati Anisah, "Kohesi Gramatikal dan Leksikal: Kajian pada Makalah Mahasiswa PAI." Indonesian Journal of Islamic Teaching, Vol. 2, No. 2, 2019. 2 http://jurnalpasca.iainjember.ac.id/ejournal/index.php/IJIT/article/view/610/100

Halliday, M.A.K., dan Ruqaiya Hasan. Cohesion in English. London: Longman Group Ltd. 1976.

Hanifa Dwinda Khairunisa, "Kohesi Leksikal Dan Kohesi Gramatikal Dalam Novel Hujan Karya Tere Liye." Jurnal dari eprints Undip. 2019. http://eprints.undip.ac.id/77150/1 
Hanifullah Syukri, "Menghidupkan Al Quran dari Perspektif Linguistik." Jurnal Sastra Indonesia. JSI, Vol. 8, No. 3, 2019. https://journal.unnes.ac.id/sju/index.php/jsi/article/view/36021

Harimurti Kridalaksana. Kamus Linguistik. Jakarta: PT Gramedia Pustaka Utama, 2008.

Jan Renkema. Introduction to Discourse Studies. Amsterdam: John Benjamins Publishing Company. 2004.

M. Kamal, "Kohesi dan Koherensi Dalam Teks Bahasa Arab". Jurnal Bina Ilmu Cendekia, Vol. 2, No. 2, 2020. https://jurnal.icjambi.id/index.php/jbic/article/view/115

Muhammad Ali Al-Khulli. Mu'jam 'Ilm Al-Lughati An-Nazariyyi: A Dictionary of Theoretical Linguistics English-Arabic. Beirut: Lebrairie du Liban. 1982.

Mulyana. "Koherensi Wacana Sesorah Perkawinan Dalam Bahasa Jawa". Yogyakarta: Tesis Program Pascasarjana Universitas Gadjah Mada, 2001.

Nurul Azizah Putri Palupi, Ilfia Rahmi Rasyid, dan Nur Hizbullah. "Repetisi Leksikal pada Al-Quran Surat Al-Kafirun" Prosiding Seminar Nasional Linguistik dan Sastra (SEMANTIKS), 2019. https://jurnal.uns.ac.id/prosidingsemantiks/article/view/39413

Puput Puji Lestari, Wiwik Darmini, dan Benedictus Sudiyana, "Kohesi Leksikal dalam Rubrik Politik Surat Kabar Kompas." Klitika:

Jurnal Ilmiah Pendidikan Bahasa dan Sastra Indonesia, Vol. 2, No. 1, 2020.

http://journal.univetbantara.ac.id/index.php/klitika/article/view/76 $\underline{1}$

Retno Widaningsih. "Kohesi Leksikal Antonimi dalam Teks Terjemahan Alquran (Surah Makiyyah). Surakarta: Skripsi UMS, 2015.

Samsul Ma'arif, "Surat Al-Baqarah: Repetisi Sebagai Piranti Kohesi dalam Al-Qur'an," Jurnal Al-Itqan, Vol. 2, No. 1, 2016. https://jurnal.staialanwar.ac.id/index.php/itqon/article/view/15

Sudaryanto. Metode dan Aneka Teknik Analisis Bahasa. Yogyakarta: Duta Wacana University Press. 1993. 
ALIBBAA': Jurnal Pendidikan Bahasa Arab, 3 (1), 2022

Tarigan, H. G. Pengajaran Wacana. Bandung: Angkasa. 1993.

Toto Edidarmo, "Wacana Naratif Kehidupan Nabi Isa dalam Al Qur'an." Arabiyat: Jurnal Pendidikan Bahasa Arab dan Kebahasaaraban, Vol. 1, No. 1, 2014. https://repository.uinjkt.ac.id/dspace/bitstream/123456789/31153/ $\underline{1}$

Wardah Hanafiah, "Analisis Kohesi dan Koherensi pada Wacana Buletin Jumat." Epigram, Vol. 11, No. 2, 2014. https://jurnal.pnj.ac.id/index.php/epigram/article/view/676

Yustina Dwinuryati, Andayani, dan Retno Winarni, “Analisis Kohesi Gramatikal dan Leksikal pada Teks Eksposisi Siswa Kelas 10 Sekolah Menengah Atas." Scholaria, Jurnal Pendidikan dan Kebudayaan, Vol. 8, No. 1, 2018. https://ejournal.uksw.edu/scholaria/article/view/1253 